San Jose State University

SJSU ScholarWorks

Master's Theses

Master's Theses and Graduate Research

1994

\title{
Evaluation of second language acquisition in a German-American kindergarten
}

Michaela Schuster

San Jose State University

Follow this and additional works at: https://scholarworks.sjsu.edu/etd_theses

\section{Recommended Citation}

Schuster, Michaela, "Evaluation of second language acquisition in a German-American kindergarten" (1994). Master's Theses. 803.

DOI: https://doi.org/10.31979/etd.ef66-xpmd

https://scholarworks.sjsu.edu/etd_theses/803

This Thesis is brought to you for free and open access by the Master's Theses and Graduate Research at SJSU ScholarWorks. It has been accepted for inclusion in Master's Theses by an authorized administrator of SJSU ScholarWorks. For more information, please contact scholarworks@sjsu.edu. 


\section{INFORMATION TO USERS}

This manuscript has been reproduced from the microfilm master. UN: films the text directly from the original or copy submitted. Thus, some thesis and dissertation copies are in typewriter face, while others may be from any type of computer printer.

The quality of this reproduction is dependent upon the quality of the copy submitted. Broken or indistinct print, colored or poor quality illustrations and photographs, print bleedthrough, substandard margins, and improper alignment can adversely affect reproduction.

In the unlikely event that the author did not send UMI a complete manuscript and there are missing pages, these will be noted. Also, if unauthorized copyright material had to be removed, a note will indicate the deletion.

Oversize materials (e.g., maps, drawings, charts) are reproduced by sectioning the original, beginning at the upper left-hand corner and continuing from left to right in equal sections with small overlaps. Each original is also photographed in one exposure and is included in reduced form at the back of the book.

Phốtógraphs inciudied in the originai manuscript have been reproduced xerographically in this copy. Higher quality $6 " \mathrm{l} \times 9^{\prime \prime}$ black and white photographic prints are available for any photographs or illustrations appearing in this copy for an additional charge. Contact UMI directly to order.

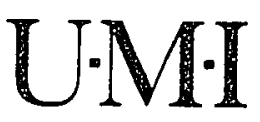

Universiav Microfilms International

A Bell \& Hcwell Information Company

300 North Zeeb Road. Ann Arbor. Mi 48106-1346 USA

$313 / 761-4700 \quad 800 / 521-0600$ 


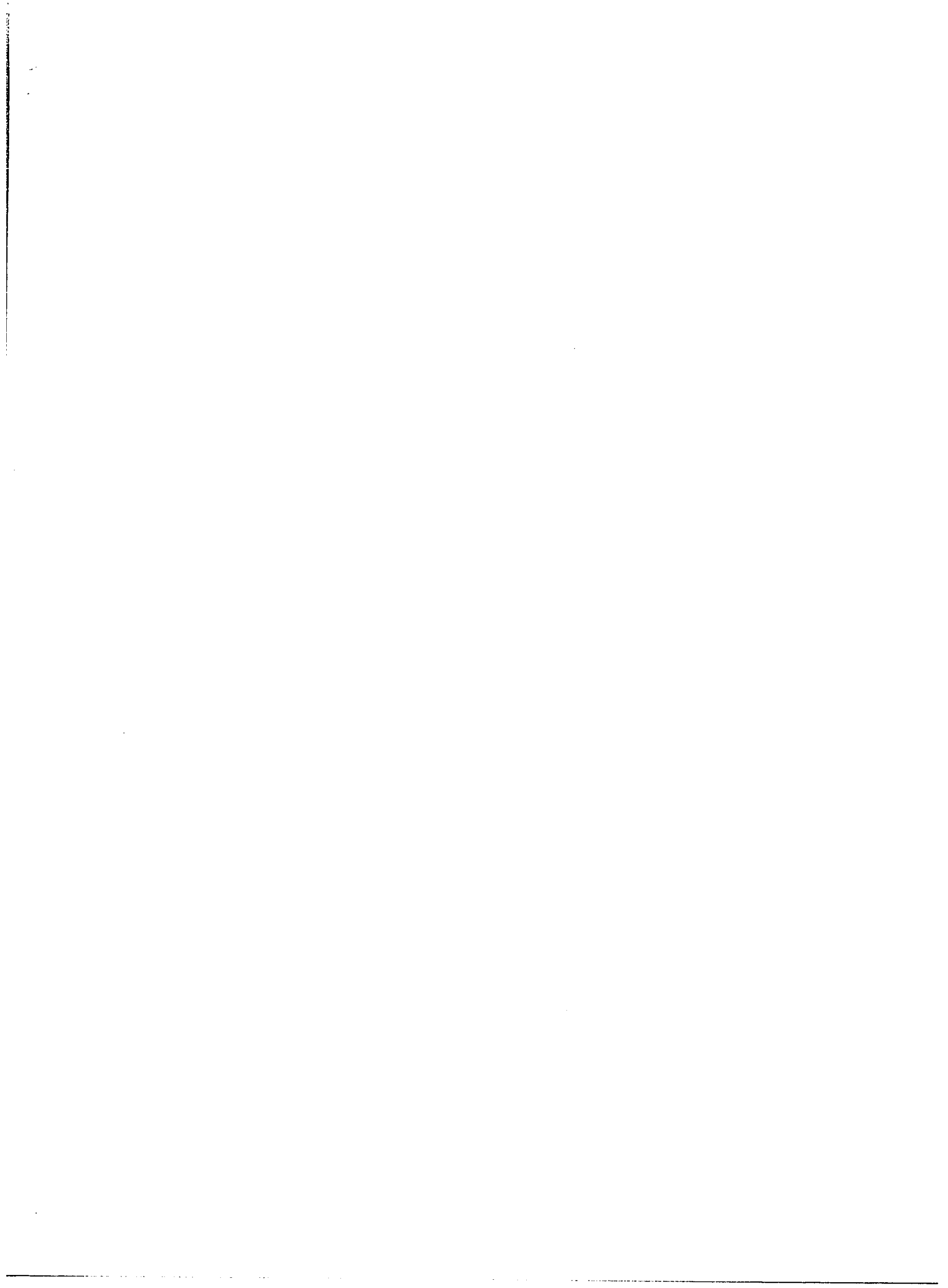


Order Number 1358227

Evaluation of second language acquisition in a German-American kindergarten

Schneider, Michaela, M.S.

San Jose State University, 1994 



\title{
EVALUATION OF SECOND LANGUAGE ACQUISITION IN A GERMAN-AMERICAN KINDERGARTEN
}

\author{
A Project Report \\ Presented to \\ the Faculty of the Department of Psychology \\ In Partial Fulfillment \\ of the Requirements for the Degree \\ Master of Science
}

by

Michaela Schneider

May, 1994 
(C) 1994

Michaela Schneider

ALL RIGHTS RESERVED 
APPROVED FOR THE DEPARTMENT OF PSYCHOLOGY

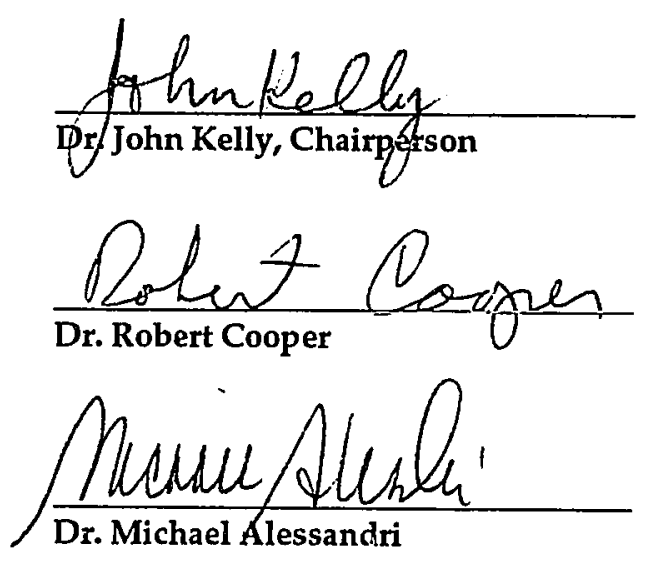

APPROVED FOR THE UNIVERSITY

Serena It Stanford 


\section{ABSTRACT \\ EVALUATION OF SECOND LANGUAGE ACQUISITION IN A GERMAN-AMERICAN KINDERGARTEN \\ by Michaela Schneider}

This pilot study addresses the topic of second language acquisition of English-speaking children in a German-American kindergarten. It evaluates a teaching method proposed by Dodson which utilizes the children's mother tongue in combination with a meaningful activity when teaching the new language. Dodson's model is contrasted with the early, total immersion approach. It advocates that children will acquire the second language in much the same manner as they had learned their mother tongue, that is, by being naturally immersed in the second language.

Data revealed that the retention of information which was presented in German was enhanced notably when using supplementary techniques, i.e. the children's first language. The increase was even more distinct when the information was followed by a related role-play. 


\section{Acknowledgments}

I sincerely thank Dr. John Kelly for supporting me throughout my years at San Jose State University and serving as the chairperson of my advisory committee. I also thank Drs. Robert Cooper and Michael Alessandri for their helpful comments on the manuscript.

I thank you, Martin, for your patience during the many hours of editing this paper on the computer. I could not have successfully completed graduate school without your wholehearted support. 


\section{TABLE OF CONTENTS}

SECTION

PAGE

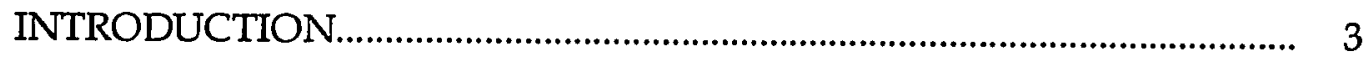

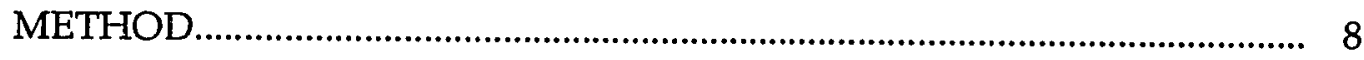

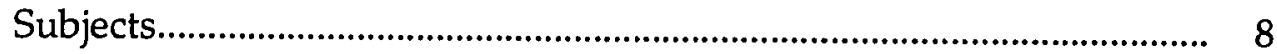

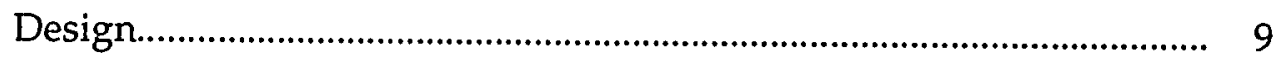

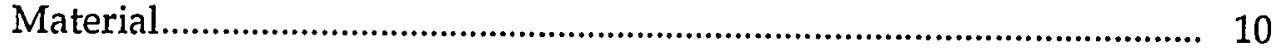

Procedure

RESULTS AND DISCUSSION........................................................... 12

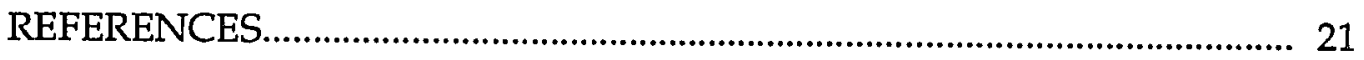

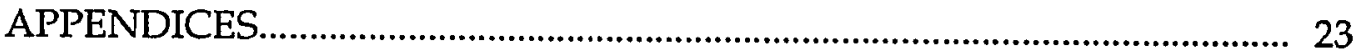

Appendix A. Stories (German and English versions)........................... 23

Appendix B. Table of Story Content...................................................... 35

Appendix C. Material (Stick-Puppets)............................................... 38

Appendix D. Children's Stories........................................................ 41

Appendix E. Raw Data..................................................................... 49 


\section{LIST OF TABLES}

TABLE

PAGE

1. Mean Retention Percentages on Each of the Three Stories................... 13 


\section{LIST OF FIGURES}

$\begin{array}{ll}\text { FIGURE PAGE } & \text { PAT }\end{array}$

1. Total percentage scores of experimental group................................. 15

2. Total percentage scores of norm group.............................................. 17

3. Total percentage scores arranged by age............................................. 18 


\title{
EVALUATION OF SECOND LANGUAGE ACQUISITION IN A GERMAN-AMERICAN KINDERGARTEN
}

\author{
Michaela Schneider
}

San Jose State University

\section{Running head: SECOND LANGUAGE ACQUISITION}

\section{Footnotes}

Requests for reprints should be sent to Michaela Schneider, Department of Psychology, San Jose State University, San Jose, California 95192. 


\begin{abstract}
This pilot study addresses the topic of second language acquisition of Englishspeaking children in a German-American kindergarten. It evaluates a teaching method proposed by Dodson which utilizes the children's mother tongue in combination with a meaningful activity when teaching the new language. Dodson's model is contrasted with the early, total immersion approach. It advocates that children will acquire the second language in much the same manner as they had learned their mother tongue, that is, by being naturally immersed in the second language. Data revealed that the retention of information which was presented in German enhanced notably when using supplementary techniques, i.e. the children's first language. The increase was even more distinct when the information was followed by a related role-play.
\end{abstract}


Evaluation of Second Language Acquisition in a German-American Kindergarten

Bilingualism is still often considered to be a language phenomenon restricted to only a few countries such as Switzerland, Belgium, and Canada. The political structure in these countries determines the necessity to acquire more than one language. However, when investigating this subject more thoroughly, it becomes evident that, rather than an exception, bilingualism is the norm in many countries (Grosjean, 1982). Germany, a country which appears to be monolingual, has almost 5 million immigrant workers who speak their native tongue as well as German to varying degrees of sophistication.

A similar situation is true for the United States. Even though the great majority is still monolingual, because of its history bilingualism in the US is extremely diverse, divided into many groups such as Native American languages, colonial languages, and recent immigrant languages from South America and Asia. In addition, a growing number of families consider the acquisition of a second language a necessary part of their children's education. This trend is especially reflected in regions with a high degree of multiculturalism such as the San Francisco Bay Area in California where parents have a choice between various bilingual institutions (French-American School; German-American School). Bilingual schools often receive applications from parents who no longer use their original mother tongue, yet would like for their children to reconnect with that part of their cultural heritage. Early enrollment in bilingual programs seems to be one way of achieving that goal.

Finding efficient methods to meet the educational needs of bilingual children outside of the family is a very important mandate for a bilingual school. 
At the beginning of the 1970's, "total immersion" (or "direct" method) as a concept for bilingual education seemed to be the answer. This model was developed in Canada by Lambert and Tucker (1972) in cooperation with a group of concerned parents in response to the changing political realities. When French became the official "langue de travail" in the Province of Quebec, fluency in that language was required. Many parents were concerned that the schools would inadequately prepare their children in this regard.

Lambert and Tucker placed a group of English-speaking children in an experimental, all-French school in St. Lambert, a suburb of Montreal, where instructions were given entirely in this second language. It was assumed that the children would learn French in much the same manner that they had learned their first language, namely by interacting with speakers of that language in a natural setting. Starting in Kindergarten (early, total immersion), the children were permitted to use their home language during the initial period of the program, but the bilingual teachers responded only in French. Mother tongue education, an integral part of the program, was not introduced until the 3rd or 4th year of schooling. Eventually, the entire curriculum became bilingual.

Validation studies of the St. Lambert experiment (Swain \& Lapkin, 1981; Tucker \& D'Anglejan, 1973) led to the conclusion that this model could be an effective means of second language acquisition. The evaluation showed that by the end of fourth grade immersion children acquired significantly more proficiency in French than children who were taught French in traditional FSL (French as a Second Language) programs. Their receptive skills (listening and reading) were comparable to French-speaking children of the same age. However, they scored behind French control groups on measures of productive 
ability, that is, in their speaking and writing skills. A further difficulty was, that even after seven years of immersion in the second language, the children's French could not be considered native-like (Cummins \& Swain, 1986; Genesee, 1978; McLaughlin, 1985).

The implementation of total immersion techniques as promoted in the St. Lambert experiment was challenged by Dodson (1985a), who has greatly aided Welsh language curriculum development in both primary and secondary schools. His findings from studies conducted with the School Council Bilingual Project (SCBP) in Wales (1968-1977) did not support the notion that total immersion at the preschool and kindergarten levels is the most effective way of acquiring a second language. "It is clear from the evidence concerning bilingual development that if an individual's preferred (mother-tongue) language is ignored, especially during the initial stages of the second-language acquisition process, he will never become a competent bilingual" (Dodson \& Thomas, 1988, p.483). In contrast to the Canadian immersion program, Welsh was the medium of instruction only in part of the school curriculum, and it was accorded less time in the school day. What made this model different from a mere partial immersion bilingual program was Dodson's communicatively-oriented approach which was implemented on a large scale and systematically evaluated (Cummins \& Genesee, 1985).

Dodson (1985b) developed a theoretical framework (hereafter referred to as Dodson's method) for multilingual development suggesting that the second language acquisition process takes place on two levels. At the message-oriented communication level the child focuses on the language itself by imitating or repeating, whereas in medium-oriented communication the child uses the 
language as a tool in order to creatively communicate. His theory rested on two assumptions: (a) if the first language is not merely tolerated but actively incorporated in the second language acquisition process (for meaning, confirmation, and consolidation), the accuracy and fluency in that language will be accelerated; and (b) the teaching of the structure of the second language must be integrated with meaningful communication, for example, followed by a related play activity. "Acquisition, retention and association may take some time; the child will tend not to speak second-language phrases or sentences unless the activity requires it" (Dodson, 1985a, p. 21). Teachers in bilingual programs ought to be aware of this sequential progression. Successful acquisition seems to depend on the fact that subject content never exceeds the language.

It was found that the SCBP was very effective in teaching Welsh at the preschool and Kindergarten levels. By the age of seven, comprehension and speaking skills were well established. The results in elementary school were less successful. This difference was attributed to a more academic and less activityoriented approach at that level (Cummins \& Genesee, 1985). An evaluation study by Price (1985) found no detrimental effects on the children's general development and no loss in their first language development.

Even though Dodson's method has been very successful, it is less widely represented in the literature than the St. Lambert project. On the other hand, the success of the Canadian model led several schools throughout Canada and the United States to employ this approach.

The German-American School (GAS), located in Menlo Park, California, is one of these schools. In 1991 a preschool/kindergarten program ( 24 children) was opened at the school. Bilingual, German-speaking as well as English- 
speaking children are admitted at both levels. All three kindergarten and preschool teachers are bilingual. Two teachers are from Germany and one from Switzerland.

The concept of integrating non-German speaking children into the program is based on the direct method, which resembles the total early immersion model described in the St. Lambert experiment. The Englishspeaking children are introduced to German in a natural way through the incorporation of play, music, arts, and story telling. Although an English teacher does join the class four times a week for a total of four hours (in order to familiarize the German children with English), the major emphasis in the curriculum is placed on the development of competence in German.

In 1991, 5 non-German speaking children were enrolled in the school. Three of the children dropped out after one year, another child after one and a half years. The reason for all four was the lack of progress in language acquisition. The fifth child did enter the 1st grade in the fail of 1993.

In contrast to the Canadian children in the St. Lambert project who came across French in their everyday environment (TV, shopping etc.), most of the English-speaking children in the GAS have little, if any, opportunity to utilize and practice their newly acquired knowledge in German, since that language is very rarely used outside of school. However, the same children, by the time they reach 1st grade, are expected to have learned enough German to be able to follow the classroom instructions in that language. On average, these children have only two years to reach a level of language comparable to children whose mother tongue is German. 
Given this requirement as well as the above mentioned drop-out rate it seemed appropriate to consider a teaching concept which might accelerate the acquisition of German for English-speaking children more effectively than the 'direct' method.

The following project was designed to determine the validity of Dodson's assumptions that the use of children's first language in combination with meaningfully related activities would support the learning of a second language more effectively than the total immersion method. A small group of Englishspeaking children was told three different German stories applying different treatment conditions $(\mathrm{A}, \mathrm{B}, \mathrm{C})$. In condition $\mathrm{A}$ they listened to a story in German; condition B entailed a story in German with an English introduction; and in condition $C$ the English introduction was followed by a role play in German.

The effectiveness of this approach was evaluated by measuring the ievel of content recalled by the children in each story. A matching norm group was chosen in order to obtain a measure for the level of content retention of native German speakers.

It was hypothesized that the frequency of the story elements produced in condition $C$ would be greater than those produced in condition $B$ which in turn would be greater than the results obtained in condition $\mathrm{A}$. Given the small sample size, this project was considered to be a pilot study.

\section{Method}

Subjects. The experimental group was comprised of three Englishspeaking children, two boys and one girl. The oldest boy, age 6, entered school 
in the fall of 1991 without any prior knowledge of German. His mother, who had studied German during her college years, began to communicate with him in that language several times a week by asking him questions about school and reading German books to him. The 5-year old girl also entered school without any knowledge of German. Although her father had taken German classes as a requirement of his doctorate program, no German was spoken at home. This child had attended the GAS since fall 1992. The second boy, age 4, entered school in fall 1992. He did not speak German, but had obtained some basic understanding of that language through his mother who was taught some German by her parents. However, her vocabulary, which was not extensive, limited her ability to communicate with her son. The dominant language spoken at home remained English. No formal testing of his entry level in German was conducted. Also, this study did not test the level of German spoken by the parents, nor did it measure the actual frequency of German used in two of the families. The information was based on self-assessment of the parents as well as the teacher's judgment and was obtained through unstructured interviews. The norm group consisted of three German-speaking children, two boys age 6 and 4, and a 5-year old girl. To ensure compatibility with the experimental group in terms of their intellectual abilities and social development, these control subjects were not chosen randomly but matched on the basis of the teachers' assessment. All participating families signed a consent form prior to inception of the project.

Design. The limited number of target subjects lent itself to a single subject design. An $\mathrm{ABC}$ paradigm was employed to measure the effectiveness of the 
early, total immersion method versus Dodson's approach, taking into account both of Dodson's assumptions:

$A=$ The children were told an unknown short story in German.

$\mathrm{B}=$ The children were told an unknown short story in German, but with an introductory explanation in English to give them a general idea about the subject matter.

$C=$ The children were told an unknown short story in German with an introductory explanation in English. In addition, they were given stick-figures and were asked to act out the story in German.

Materials. The stories (see Appendix A) were written by the investigator based on different picture-books by Bill Peet $(1972,1975,1978)$. The Kindergarten teachers assessed age-appropriateness for German children (length, complexity of plot, vocabulary) using a rating scale from 1 (easy) to 5 (difficult). Two stories, "Cecilia" and "Rufus," were rated as moderately difficult $(3 ; 3 ; 3)$, "Magnus" was considered slightly more difficult $(3 ; 4 ; 4)$ by two of the three teachers. Finally, the stories were divided into various element categories (events, places, and characters; see Appendix B) by the investigator as well as an by independent high-school teacher from the GAS. The total score obtainable based on these categories for story 1 ("Cecilia") was 35, for story 2 ("Rufus") 34, and for story 3 ("Magnus") 38.

For the third treatment condition the investigator prepared stick-figures (see Appendix C) taken from Bill Peet's picture-books. All stories, including those of the teacher, were tape-recorded 
Procedure. All children were informed one day prior to the beginning of the experiment of their participation in this project. Children's consent had been obtained verbally at that time. One child of the norm group decided against participation on the morning of the first experiment. After conferring with the teachers and obtaining parental agreement, a matching substitute child was asked to participate. The investigator explained the procedures and gave them an opportunity to become familiar with the equipment (tape-recorder).

To reduce a potentially disrupting impact on the classroom routine, the children were called for a small group activity after the free play period by their teacher (about 10:00 a.m.). She told the stories first to the experimental group, followed by the norm group. Due to the nature of the project, the teacher was unable to be kept blind to the experimental conditions. The teacher's potential for bias was minimized by asking her to read the stories verbatim. The three different treatment conditions took place within a two-day interval.

The experimental group was introduced to the first story with the following instruction given in German: "I am going to read you a story. Please listen carefully, so that you can tell the story again later to Michaela." The second and the third stories were introduced in the same manner; in addition the teacher gave a short summary of each story in English (see Appendix D). The summaries were kept short and general. After the completion of story 3 , the teacher brought out the stick-figures, explaining to the children in German: " I brought all the animals that appear in this story and I want us to play the story with these animals. Lets talk about the events in that story. Which animal came along first? The ant! Good, who wants to play that animal?... " The children roleplayed the entire story supported by the teacher. She prompted them to find the 
right wording or confirmed the correct pronunciation, and, if necessary, used the English connotation to clarify the meaning in German. Each child was encouraged to repeat the newly learned vocabulary in German. No specific guidelines had been given to the teachers pertaining to this role play.

After nap-time (about 1:00 pm), the children were individually called by the investigator and asked in German to repeat the story:" Do you remember the story about Cecilia (Rufus; Magnus)? Please tell me what happened in that story." The investigator needed to prompt the children (especially the two younger children) in both groups by asking "what happened then" or "what else do you remember," but any leading questions were avoided.

After the transcription of the recorded stories, the story content recalled by the children was quantified according to the table of elements developed for each story. If the children used a correct synonym in German, it was scored as correct (these synonyms were also listed in parenthesis in the table of elements). To ensure correct scoring the investigator and the high-school teacher rated the stories independently, obtaining the same results.

\section{Results and Discussion}

It was hypothesized that the frequency of the story components produced in condition C (story 3 ) would be greater than those produced in condition $B$ (story 2) which in turn would be greater than the results obtained in condition A (story 1 ).

Mean percentages of story components retained for each of the three stories by the experimental and the control groups are presented in Table 1. As expected, 
Table 1

Mean Retention Percentages on Each of the Three Stories

\begin{tabular}{lccc}
\hline Group & Story 1 ("Cecilia") & Story 2 ("Rufus") & Story 3 ("Magnus") \\
\hline Experimental & 17.3 & 24.7 & 45 \\
Norm & 34 & 33.7 & 64 \\
\hline
\end{tabular}


the results indicate a significant difference in the amount retained between story $1(17.3 \%)$, story $2(24.7 \%)$, and story $3(45 \%)$. The Chi-square analysis as a nonparametric test was performed on these data because of the small sample size $\left(\underline{x}^{2}=14.19, \underline{\mathrm{df}}=2, \mathrm{p}<.001\right)$.

These data demonstrate that the retention of information presented in German (i.e., new vocabulary) was notably enhanced for the English-speaking children when a play activity was combined with utilizing their mother tongue for clarification and explanation of the subject matter. As presented in Figure 1, the amount of information retained by Child 2 was particularly striking. She increased her total percentage scores from $18 \%$ in story 2 to $61 \%$ in story 3 . Child 3 increased in total amount of scores from $9 \%$ in story 2 to $24 \%$ in story 3 . The percentage scores of Child 1 indicate a lesser, although steady increase in overall content retention from story 1 to 3 . Although he obtained his highest score $(50 \%)$ on story 3 , the treatment method of condition $C$ did not result in a marked difference for that child. This finding could be attributed to this child's specific learning style and verbal comprehension abilities. Overall, the performance of all three children in condition $C$ surpassed that on conditions $A$ and B, even though that story ("Magnus") was rated slightly more difficult than the other two stories by the teachers.

It could be speculated that the combination of auditory with visual teaching methods was more appealing to the younger children, resulting in a more distinct increase of scores from story 2 to story 3 . This assumption would be consistent with what is known about how children operate and learn, that is, through play which is their most natural and comfortable medium of 


\section{Experimental Group}

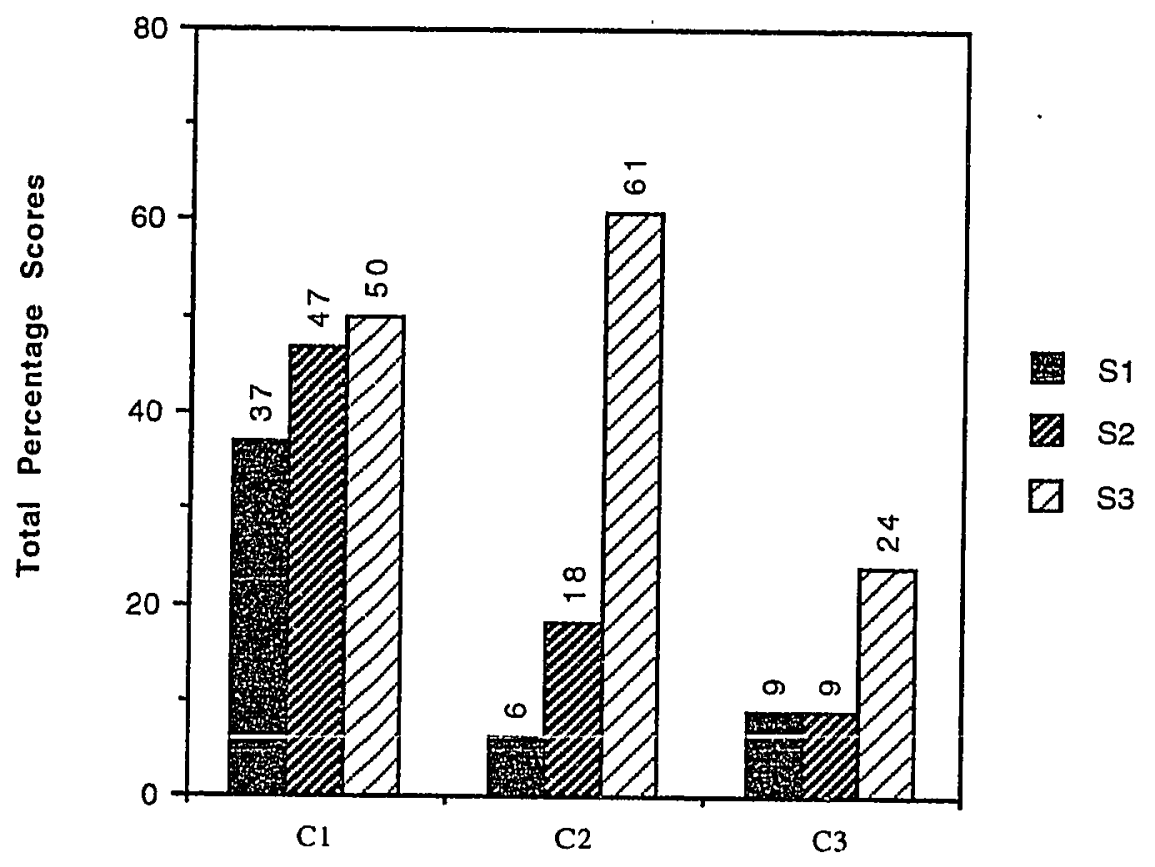

\section{Crild}

Figure 1. Total percentage scores of experimental group. 
of communication (Landreth, 1991; Moustakas, 1992; Oaklander, 1988; Schaefer \& O'Connor, 1983). Miller (1989) noted that children are much more likely to remember material which is presented meaningfully for them. By incorporating the role play into the language acquisition process, the children were met at their developmental level.

A practice effect (the children became familiar with the experiment and its procedures) may have been an additional contributing factor, as is evident in the results (see Figure 2) of the norm group in condition C (story $1=34 \%$; story $2=$ $33.7 \%$, story $\left.3=64 \% ; \underline{x}^{2}=13.8, \underline{d f}=2, \underline{p}<.001\right)$. No learning effect had taken place for the norm group with regard to condition $B$, whereas the experimental group increased its mean retention from $17.3 \%$ to $24.7 \%$ with an English introduction (see Table 1).

As expected, the German-speaking children obtained higher scores in all three stories when compared with non-German speaking children. Child 5 was an exception to this trend, possibly due to individual verbal comprehension capabilities.

Quite remarkably, the quantity of information recalled by the Englishspeaking children during the third treatment condition was comparable to the amount of content retention of the norm group obtained during the first story. Child 2 and Child 3 even surpassed their counterparts in the norm group in this regard (see Figure 3).

Given the small sample size, it seemed appropriate to look at individual factors which might have contributed to the scores of the English-speaking children. Although not explicitly tested for, motivation appeared to be an 
Norm Group

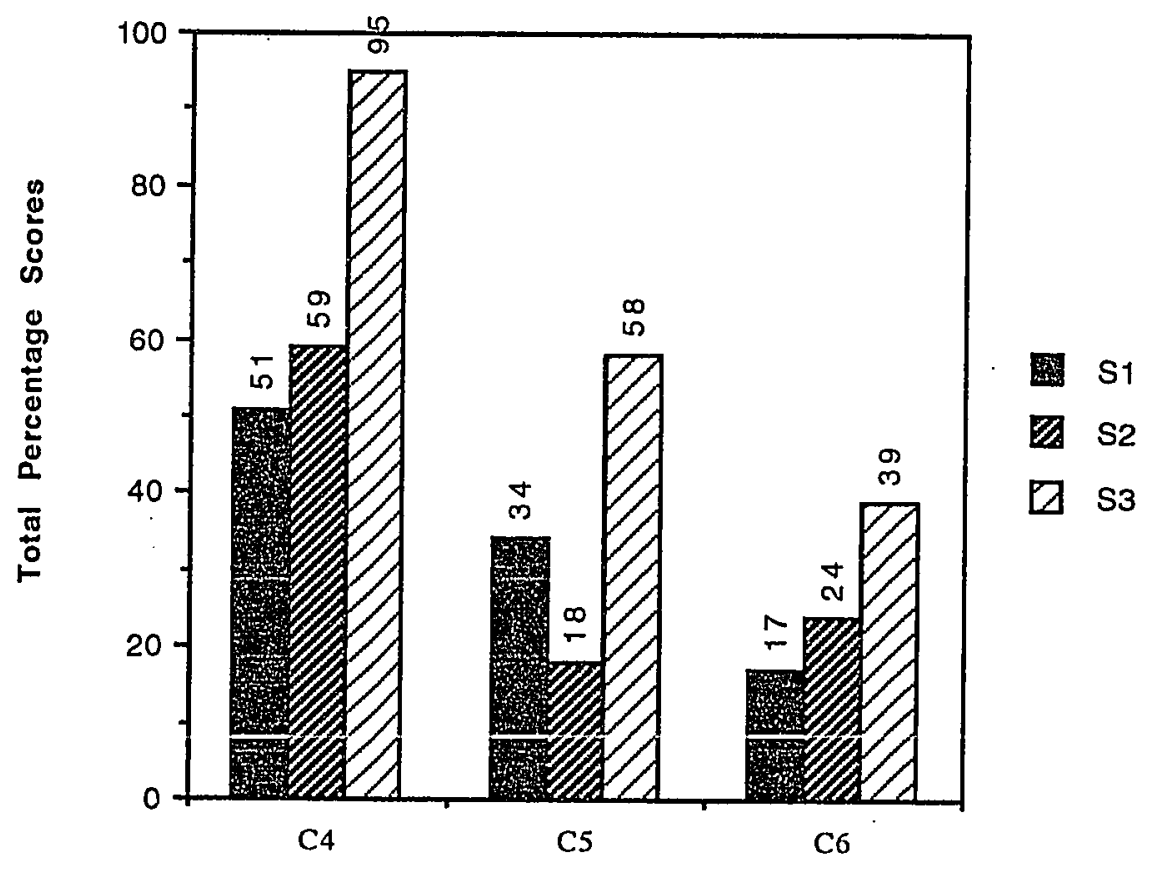

Child

Figure 2. Total percentage scores of norm group. 


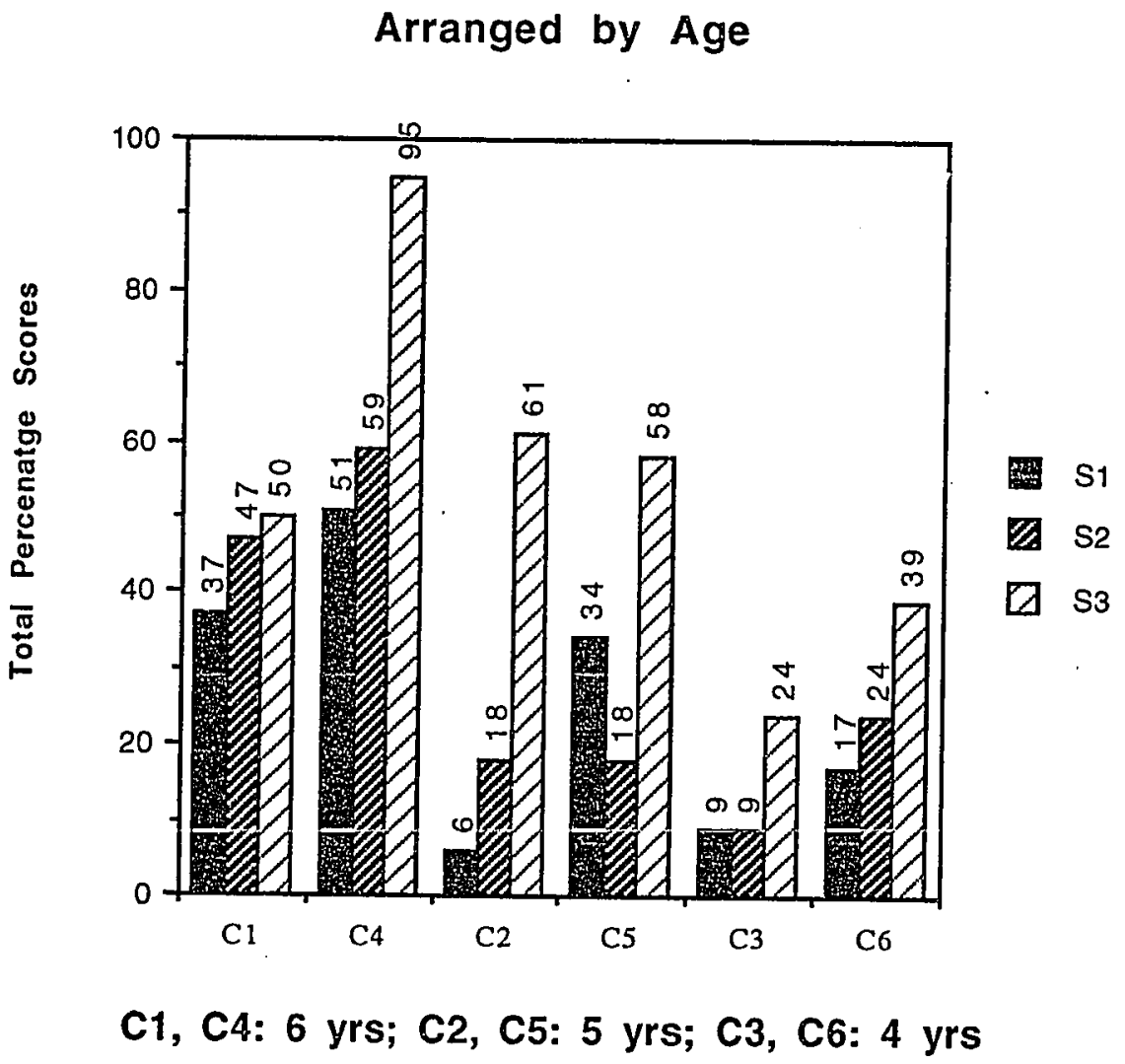

Figure 3. Total percentage scores arranged by age. 
important variable pertaining to the results. Gardner and Lambert (1972) referred to "integrative and instrumental motivation" to explain why some individuals acquire a foreign language quickly and expertly. Instrumental motivation taps into a person's need to achieve and gain social recognition, whereas integrative motivation reflects interpersonal motives such as wanting to be liked and to belong. The authors found that integrative motivation seemed to have had a greater effect on the acquisition process due to the endurance of personal relationships and group attachments. Whatever the individual striving motive, research has demonstrated that having the opportunity and/or the aptitude to learn a second language without motivation resulted in lower achievement (Baker, 1988).

With regard to the children participating in this study, all of them came from a family background with very high educational standards and expectations (in all three families, one parent had obtained a Ph.D., the other parent had graduated with a Master's degree), which might serve as a motivation for their children to excel.

Child 3 communicated on a limited but consistent basis with his mother in German, making his placement in a German-speaking school meaningful for him. Likewise for Child 1, German created a special relationship with his mother, who occasionally read German books to him. He was described by his parents as quite competitive, and he seemed to draw a great deal of satisfaction and reassurance from his success in acquiring a second language. A strong sense of achievement combined with the need to relate well to her peers and teachers appeared to be the driving force for Child 2. In contrast to Child 1 and Child 3 , 
she spent much of her time with German-speaking classmates during her first year in school.

In conclusion, the data obtained in this exploratory project provide support for Dodson's theory that the use of a child's first language in combination with related play enhances the learning of a second language more than the early, total immersion approach. Given the small sample size, strong generalizations cannot be made. However, these results should prove helpful in determining variables that need to be controlled in later studies, such as the level of exposure to the second language. Ideally, further research projects will be able to draw from a much larger pool of subjects, testing same gender and same age groups with varying degrees of language acquisition. Also, they will be able to conduct follow-up studies as the children progress through grade school.

The English-speaking children need to develop an adequate working level in German if they are to compete successfully with the German-speaking children later in school. In view of the potential, long-lasting impact on their development, it is appropriate continuously to examine and, where necessary, revise the current teaching methods at the Kindergarten level to ensure that the children are well prepared. The preliminary results of this project suggest the possibility that this goal can be reached more successfully by incorporating Dodson's approach. 


\section{References}

Baker, C. (1988). Key issues in bilingualism and bilingual education. Clevedon, England: Multilingual Matters, Ltd.

Cummins, J., \& Genesee, F. (1985). Bilingual education programes in Wales and Canada. In C. J. Dodson (Ed.), Bilingual education: Evaluation, assessment and methodology (pp. 37-49). Cardiff, England: University of Wales Press.

Cummins, J., \& Swain, M. (1986). Bilingualism in education: Aspects of theory, research and practice. New York: Longman.

Dodson, C. J. (1985a). School council bilingual education project 1968-1977: An independent evaluation. In C. J. Dodson (Ed.), Bilingual education:

Evaluation, assessment and methodology (pp. 5-36). Cardiff, England: University of Wales Press.

Dodson, C. J. (1985b). Second language acquisition and bilingual development: A theoretical framework. Lournal of multilingual and multicultural development, 6, 325-345.

Dodson, C. J., \& Thomas, S. E. (1988). The effect of total L2 immersion education on concept development. Lournal of multilingual and multicultural development, 9 , 467-485.

Gardner, R. C., \& Lambert, W. E. (1972). Attitudes and motivation in second language learning. Rowley, MA: Newbury House.

Genesee, F. (1978). A longitudinal evaluation of an early immersion school program. Canadian Journal of Education, 33, 31-50.

Grosjean, F. (1982). Life with two languages: An introduction to bilingualism. Cambridge, MA: Harvard University Press. 
Lambert, W. E., \& Tucker, G. R. (1972). Bilingual education of children: The St. Lambert experiment. Rowley, MA: Newbury House.

Landreth, G. L. (1991). Play therapy: The art of the relationship. Muncie, IN: Accelerated Development Inc.

McLaughlin, B. (1985). Second-language acquisition in childhood: Vol.2. School-age children. Hillsdale, NJ: Lawrence Erlbaum.

Miller, P. H. (1989). Theories of developmental psychology. New York: W. H. Freeman and Company.

Moustakas, C. E. (1992). Psychotherapy with children. The living relationship. Greeley, CO: Carron Publishers.

Oaklander, V. (1988). Windows to our children. Highland, NY: The Center for Gestalt Development, Inc.

Peet, B. (1972). The ant and the elephant. Boston: Houghton Mifflin.

Peet, B. (1975). Cyprus, the unsinkable sea-serpent. Boston: Houghton Mifflin.

Peet, B. (1978). Eli. Boston: Houghton Mïifflin.

Price, E. (1985). Schools council bilingual education project 1968-1977: An assessment. In C.J. Dodson (Ed.), Bilingual education: Evaluation, assessment and methodology (pp. 51- 159). Cardiff, England: University of Wales Press.

Schaefer, C. E., \& O'Connor, K. J. (Eds.). (1983). Handbook of play therapy. New York: John Wiley \& Sons.

Swain, M., \& Lapkin, S. (1981). Evaluating bilingual education: A Canadian case study. Clevedon, England: Multilingual Matters, Inc.

Tucker, G. R., \& D'Anglejan, A. (1973). French immersion programs: A pilot investigation. Language Sciences, 25, 19-26. 


\section{Cecilia (606 words)}

\section{APPENDIX A}

Tief unten im grossen Ozean lebte einmal ein riesiggrosses Seeungeheuer namens Cecilia. Obwohl sie ganz schrecklich aussah, brauchte man keine Angst vor ihr zu haben. Sie schwamm nur den ganzen Tag im Wasser herum und langweilte sich sehr. " Oh, wie bin ich diese Rumschwimmerei leid, ich wünschte, es würde mal etwas wirklich Aufregendes passieren", dachte sie oft. Und tatsächlich, schon nach kurzer Zeit später bemerkte sie ein schwerbeladenes Segelschiff. Es hiess Windrose, und da Cecilia im Augenblick nichts Besseres zu tun hatte, beschloss sie, dem Schiff heimlich $z u$ folgen. Vielleicht würde ja etwas Aufregendes geschehen. Drei lange Tage und Nächte schwamm sie hinterher, immer darauf bedacht sich nicht sehen zu lassen, denn sie wollte niemanden erschrecken. Dann, ganz plötzlich am vierten Tag, wurde es plötzlich ganz ruhig. Das Schiff blieb einfach stehen und bewegte sich nicht mehr. "Oh je," begann der Kapitän zu jammern, "wir sind in einer Windstille. Das kann Wochen dauern bis wir wieder Wind bekommen! Die Passagiere wurden sehr aufgeregt und eine alte Dame meinte ängstlich: "Wie lange reicht den das Essen und Trinken. Wenn wir zu lange hier liegen müssen, haben wir nichts mehr und werden verhungern!'"Leider können wir nur abwarten", erwiderte der Kapitän ernst. Als Cecilia hörte, wie gross die Angst an Bord war, beschloss sie, etwas zu tun. Leise näherte sie sich in der Nacht dem Schiff, holte ganz tief Luft und begann vorsichtig in die Segel zu pusten und immer mehr zu pusten, bis sich die Windrose in Bewegung setzte und aus der Windstille heraussegelte. Die Passagiere jubelten, aber der Kapitän war immer noch ernst. Er zeigte auf schwarze, drohende Wolken am Himmel und meinte besorgt:" Das sieht nach einem schweren Sturm aus. Unser Schiff kann umkippen!" Kaum hatte er das gesagt, als auch schon ein starker Wind das Schiff erfasste und kräftig hin und her schüttelte. Riesige Wellen schwappten über die Windrose, und die alte Dame begann aus Leibeskräften zu schreien:"Hilfe, Hilfe, wir gehen unter!" Cecilia zögerte nicht eine Sekunde, schwamm auf das Schiff zu, rollte ihren langen Schwanz um das Schiff und holte wieder tief Luft. Sie blies sich selbst auf wie einen Rettungsring und die Windrose schwebte nun ganz sicher über die Wellen. Als der Sturm vorüber war, blies sie erschöpft die Luft aus und tauchte wieder ins Wasser, um nach dieser Anstrengung etwas auszuruhen. Kaum aber hatte sie 
die Augen geschlossen, da hörte sie den Kapitäin aufgeregt rufen: " Alle Mann an die Segel, wir werden von Piraten verfolgt!" Die Seeleute taten alles um zu fliehen, aber das Piratenschiff war schneller. Nachdem sie die Segel mit dicken Kanonenkugeln kaputtgeschossen hatten, kamen sie immer näher und hätten die Windrose wohl überfallen, wenn Cecilia nicht noch einmal zu Hilfe gekommen wäre. Sie tauchte tief ins Wasser hinunter und schoss dann schnell wie eine Rakete nach oben auf das Piratenschiff zu, um es mit ihrem gepanzerten Kopf zu zerschmettern. Das Piratenschiff war vollkommen zerstört und Cecilia hatte fürchterliche Kopfschmerzen! Die Passagiere schauten voller Angst ins Wasser. Sie glaubten, das Ungeheuer würde nun das gleiche mit ihnen machen. Aber zu ihrem grossen Erstaunen nahm Cecilia die schwere Ankerkette in ihr Maul und begann die Windrose langsam hinter sich herzuziehen. Allmählich wurde sie schneller " Das ist ja ist unglaublich", jubelte der Kapitän, "das Ungeheuer zieht uns nach Westen. So werden wir bald an Land kommen!" Und tatsächlich, nach einigen Tagen sahen die Passagiere die Küste vor sich. Mit allerletzter Anstregung zog Cecilia das Schiff an Land und tauchte erleichtert ins Wasser zurück. Sie hörte nicht mehr, wie die alte Dame noch "Vielen, vielen Dank!" rief; Cecilia hatte genug Aufregung gehabt. Sie suchte sich eine stille, kleine Insel und schlief,- einen ganzen Monat lang! 


\section{Cecilia (579 words) English version}

Deep down in the great ocean there lived a giant sea serpent named Cyrus. Even so he looked horrible, he wasn't the least bit fierce. All he did was wander in the sea and one day he thought to himself:"I'm tired of wandering. I'd like to have some fun for a change." Suddenly he noticed a huge ship named Primose sail by with many people on board. "Well, since I have nothing better to do, I might as well follow them and see whether something exciting will happen." He didn't want to scare anyone so, so he went churning along at a slow pace, careful to keep at a distance. For three days the ship sailed without the least bit of excitement. Then on the fourth day, a great stillness settled over the sea. "Oh, my god," cried the captain, "we have run into the doldrums. It can take days, maybe weeks until the wind returns." One of the passengers, an old lady, became very worried: "But we might run out of food and water. Is there nothing we can do?" "All we can do is wait," answered the captain somberly. Cyrus was also worried and suddenly he had an idea. Quietly he slipped up close behind the Primose and very gently he began puffing at the sails. Slowly the ship started to move and Cyrus kept blowing all night until a stiff head wind came up and the ship could sail on his own. The passengers were delighted, but the captain did not join in the jubilation. "Look at the clouds, there will be a big thunderstorm", he warned. Within a very short time giant, towering waves crashed over the ship which began to founder. "Help, help," shouted the old lady, "we are sinking, help!" Cyrus realized that his support was need again. He flung himself around the ship and puffed himself up with air into a huge life preserver. Thus he kept the ship afloat until the storm was over. With great relieve and quite exhausted he let go of the ship and was about to take a nap, when the next danger approached. Pirates were chasing the Primrose, closing in fast. The captain tried everything to escape, but after the pirates had shot the sails, they had caught up in less than a minute and pulled alongside. The old lady was so scared that she fainted and this was when Cyrus decided to interfere. He dove deep into the sea, then wheeling sharply he shot straight up like a rocket cracking the pirate ship apart with his head like a nutshell. The ship was wrecked - and so was Cyrus. He had almost knocked himself out. The captain and his passengers were holding their breath. They were scared that the monster would destroy them, too. But to everybody's great surprise, Cyrus suddenly gripped the anchor chain tightly in 
his jaws and pulled the ship slowly through the water. "It's unbelievable," shouted the captain, "this monster is taking us west. If he keeps going, we'll soon hit land!" Finally one morning the lookout was shouting: "Land ho! and at last the perilous voyage was over. Cyrus carried the Primrose up on the beach and with an enormous sigh of relief he wandered off into the sea again, looking for a peaceful island."I guess I've had enough excitement to last for a while. What I need is a good long rest"! 


\section{Rufus (615 words)}

In Afrika lebte einmal ein alter Löwe, namens Rufus. Seine Mähne war ganz dünn geworden und er war so schwach, dass er gar nicht mehr richtig brüllen konnte. Wenn es etwas zu fressen gab, konnte er nicht mehr mit den anderen Löwen um die besten Stücke kämpfen, sondern musste sich den Rest mit den Geiern teilen. Er mochte diese Vögel gar nicht. Sie waren so hässlich, assen nur totes Fleisch und machten immer so viel Lärm. Eines abends, als er gerade beim Essen war, begann der Geier James fürchterlich zu schreien. "Aua, aua, loslassen!" Wütend, dass man ihn störte, drehte Rufus sich um. Ein Schakal hatte den Geier gierig am Flügel gepackt. Rufus vergass, dass er ja ein alter, schwacher Löwe war und verjagte den Schakal laut brüllend. "James, James", heulten die anderen Geier entsetzt, "hat er dir wehgetan, bist du verletzt? "Nein", meinte James noch ganz ausser Atem. "Mit Hilfe von Rufus bin ich noch einmal heil davon gekommen. Wie kann ich mich nur bei Dir bedanken"? Rufus drehte sich um und während er langsam davon humpelte, knurrte er mürrisch: "Ach, lasst mich bloss in Ruhe!" Aber die Geier dachten nicht daran. Sie bewunderten Rufus so sehr um seine Tapferkeit, dass sie ihm von nun an immer folgten. Legte er sich zu einem Mittagsschläfchen hin, liessen sich die Geier auf einem Baum nieder. Wollte er einen kleinen Spaziergang machen, flogen sie hinter ihm her. Rufus wurde immer ärgerlicher über diese Störung. Aber die Geier liessen ihn nicht mehr aus den Augen, damit sie sofort zur Stelle sein konnten, sollte Rufus Hilfe brauchen. Und tatsächlich, eines Morgens entdeckte James in der Ferne zehn Jäger, mit grossen Speeren, die auf Löwenjagd gingen. Aufgeregt flog er zu Rufus der noch schlief, und rief:" Rufus, aufwachen, die Jäger kommen!"."Oh,je," jammerte Rufus, "was mach' ich denn bloss. Wo soll ich denn hin?" "Schnell," drängte James, "zum Sumpf, folge mir!". So schnell er konnte, lief Rufus hinter dem Geier her. Bald fing er an, heftig zu schnaufen, am liebsten hätte er sich hingelegt. Zum Glück hatten sie den Sumpf bald erreicht. 'Hier finden dich die Jäger nie," meinte James. Der Löwe wollte sich gerade erleichert ausruhen, oh Schreck, da sah er ein riesiges Kokodil. Es kroch langsam auf ihn zu. Rufus drehte sich entsetzt um: "Hilfe, wo verstecke ich mich denn jetzt?" Ich glaub', ich fall vor Angst gleich tot um", jammerte er. "Genau," schrie James, "das ist es. Das ist die Idee. Schnell, leg' dich hin und stell dich tot!" Das liess sich Rufus nicht zweimal sagen. Er rollte sich auf den Rücken, streckte alle Beine von sich und 
kniff die Augen fest zusammen. "Jetzt bleib so liegen," meinte James. "Rühr dich bloss nicht vom Fleck. Ich komme gleich wieder!" Rufus' Herz klopfte heftig, aber er wagte es nicht, die Augen zu öffnen. Plötzlich hörte er ein Rauschen in der Luft. James hatte all seine Freunde geholt. Langsam setzten sich die Geier auf Rufus, und taten so, als ob sie ihn mit ihren Schnäbeln picken würden.

"Vorsichtig, Freunde," mahnte James, " wir wollen ihm nicht wehtun!" Und schon waren die Jäger da. Sie schlichen näher und schauten ganz erstaunt auf Rufus. "Na, so was," sagte der Anführer, "der Löwe ist ja schon tot. Er war ja auch schon ganz alt und schwach. Hier gibt es für uns nichts mehr zu tun!" Kaum waren die Jäger verschwunden, flatterte James lachend auf und ab: "Ha, die haben wir aber schön an der Nase herumgeführt! Rufus, du bist ein grossartiger Schauspieler!" Von dem Tag an fand Rufus es gar nicht mehr störend, dass die Geier ihm folgten. Im Gegenteil, er freute sich, dass er nie mehr alleine war. 


\section{Rufus (573 words) English version}

Once upon a time in Africa there lived an old and very weak lion named Rufus. Whenever the other lions gathered to eat, he didn't dare to join in; it was much too rough. All he could do was to wait until everybody had his share, except the vultures and himself. These noisy birds were a real nuisance to him and he tried to avoid them as best as he could. "I'll never make friends with these creatures", he thought to himself. Then one day an old vulture named James let out a terrible scream. He wouldn't stop until Rufus turned on him with a snarling fury. All of a sudden he realized that a jackal had caught James by the wing. He took pity on the poor bird and with a wild swing of his paw he sent the jackal yelping away, only to find himself surrounded by a dozen fussy vultures. They praised him for saving James' life, but he just snarled:"There's nothing great about saving a worthless old bird. So forget about it!" But the vuitures were never going to forget Rufus, and to his great dismay they began following him wherever he went. If he took a morning stroll, his faithful friends came fluttering along. If he wanted to take a nap under a tree, they were right above him, making sure that he was all right. One day James detected a band of hunters armed with spears who were tracking a lion. He guessed whose paw prints they were and he immediately took off to warn Rufus. The old cat was under his tree in a deep nap. "Wake up, wake up, "James yelled, "lion hunters are coming, they are hot on your trail!" Rufus sat up with a shiver, wailing:"What'll I do? Where' 11 I go?" "To the swamp! Quick! Follow me!" Off they went in a hurry, but when they reached the edge of the swamp, they noticed it was full of crocodiles. Rufus was desperate: "Oh dear, those crocodiles will finish me off. Where do I hide now? I'm going to die, right now!"' "Yes, yes, that's it", cried James. "Roll over and play dead. Great idea! Go ahead!" Rufus looked puzzled, but he sprawled out on his back in the weeds:" Like this?" "Perfect, Rufus, now hold it. Stay put while I get the others." In a flash the old vulture was back with his flock of bone-picking friends, shouting instructions:"Swarm all over him! Peck! Peck! Peck! Make it look real, but don't get too rough". And in an instant the vultures were all over Rufus, pecking away at their make-believe feast. A moment later the hunters came charging along over a hill all set to attack. But when they caught sight of that old lion being pecked by a flock of wild vultures, they gaped in surprise:"How can that be? What happened to that cat? Well, we can't fight a 
dead lion", they said and grouching and grumping about their bad luck the hunters trotted away. "Great," shouted James, "I do believe we fooled them." $\mathrm{He}$ watched them until they had disappeared and then cheered:" Come to life old lion! That was a fantastic act. Just super! Rufus was very grateful for his friends. From then on, whenever he flopped down to take a cat nap he made sure his friends were there. 


\section{Magnus (611 words)}

An einem schönen Morgen krabbelte eine winzige Ameise einen Blattstengel empor, um sich den Fluss von oben zu besehen. Plötzlich kam ein starker Windstoss und bliess sie auf's Wasser, aber bevor sie hineinfiel, konnte sie sich an einem Baumstumpf festkrallen. Erleichtert atmete sie auf und sah im gleichen Moment eine Schildkröte am Ufer entlang kriechen. "Hallo, liebe Schildkröte. Würdest Du bitte so freundlich sein und mich zurückbringen." Die Schildköte schüttelte nur ihren Kopf, meinte hochmütig "nein, nein, ich hatte heute schon mein Bad", und zog weiter. Sie war auf der Suche nach einem warmen Stein, auf dem sie sich ausruhen wollte. Als sie einen passenden gefunden hatte, begann sie sich hinaufzuziehen. Plötzlich verlor sie das Gleichgewicht, rutsche runter und landete auf ihrem Rücken. Hilflos lag sie nun da und alles Strampeln mit den Beinen nützte nichts, sie konnte sich alleine nicht umdrehen. Als sie sich nach Hilfe umblickte, erspähte sie einen Nashornvogel hoch oben im Baum. "Hallo, lieber Vogel", rief sie so laut sie konnte. Würdest Du so nett sein und mir wieder auf die Beine helfen?" "Auf keinen Fall", erwiderte der Nashornvogel, "sei das nächste Mal nicht so tollpatschig"! Während er noch sprach, kippte sein Nest zur Seite und ein grosses Ei fiel auf den weichen Boden. "Oh, je", rief er entsetzt, flog hinterher und versuchte das Ei mit dem Schnabel aufzupicken. Aber es war viel zu schwer, er konnte es nicht ins Nest zurückbringen. Verzweifelt blickte er sich um und sah zu seiner Erleichterung eine Giraffe des Weges kommen. "Hallo, liebe Giraffe," schrie der Nashornvogel aufgeregt, "könntest Dü mir bitte das Ei wieder in mein Nest heben?" "Ha, ha", lachte die Giraffe, "da würde ich ja schön dumm aussehen, nein wirklich!" Lachend stolzierte sie weiter, um sich leckere Blätter von den Bäumen zu zupfen. Sie war so beschäftigt, dass sie nicht merkte, wie sich ihre langen Beine immer mehr im Gestrüpp verhedderten. Sie konnte sie nicht mehr herausziehen; sie zappelte und zerrte, aber je mehr sie sich bewegte, um so fester schlangen sich die Pflanzen um ihre Beine. Schliesslich gab sie auf, und blieb erschöpft auf dem Waldboden liegen.

Da waren sie nun alle in grosser Not, die Ameise, die Schildkröte, der Nashornvogel und die Giraffe. Was wäre wohl aus ihnen geworden, wenn nicht zufällig ein gutmütiger Elephant namens Magnus vorbeigekommen wäre. Er hob die kleine Ameise vorsichtig aufs trockene Ufer. Ganz zart rollte er die Schildkröte wieder auf ihre Beine. Dann hob er sachte das Ei vom Boden auf und 
legte es zurück ins Nest. Zum Schluss befreite er die Beine der Giraffe vom Gestrüpp. Magnus war sehr zufrieden mit sich; was er mit seinem Rüssel alles machen konnte! Stolz trompetend stampfte er durch den Urwald und gab dabei nicht mehr auf den Weg acht. Plötzlich sackte unter ihm der Boden weg, und er stürzte mit lautem Gebrüll in eine tiefe Grube. "Hilfe, Hilfe!" schrie er immer wieder, aber: vergebens. Hilflos lag er so für lange Zeit, bis er auf einmal über sich das Geräusch von vielen kleinen Fusstritten hörte. "Wer ist das"?, rief er aufgeregt. "Ich, die Ameise, die Du heute morgen gerettet hast. Ich bin mit fünfundneunzig-tausend Freunden gekommen, um Dir zu helfen." Aber ich bin doch viel zu schwer", lachte Magnus. "Wart's ab," meinte die Ameise bestimmt. "Kommt, Freunde, an die Arbeit." Magnus spürte wie Tausende von Ameisen unter seinen Rücken krochen. Es kitzelte ein bisschen, und voller Aufregung hielt er den Atem an. Tatsächlich, ganz langsam bewegte er sich nach oben und gelangte nach unendlich langer Zeit aus der Schlucht. Er fühlte sich auf einmal gar nicht mehr so stolz, und freudig brachte er die Ameisen nach Hause. 


\section{Magnus (567 words) English version}

One morning a tiny ant crawled up a tall blade of jungle grass for a view of the river. Suddenly a breeze came and sent him sailing off into the water, but before he fell into it, he landed onto a snag in the middle of the river. After a little while a turtle came creeping along the riverside and the ant called anxiously: "Please, dear turtle, could you give me a lift back to dry land"? The turtle shook her head and merely replied: "No, I have had my swim for today," and off she went searching for a warm rock where she could rest. When she found it, she slowly crept up, but all of a sudden went toppling backwards and landed upside down on her shell. All kicking was in vain, the turtle could not turn herself over to her feet. As she strechted her neck looking for help, she saw a hornbill roosting on her nest. "Please, dear hornbill," begged the turtle, "would you help me back to my feet?" "No, I won't," answered the hornbill, "don't be so clumsy the next time". As she leaned over to say more, the bird tipped her nest and one big egg fell on the ground. The hornbill desperately tried to take it off and fly back to her nest, but the egg was too heavy for her. Fortunately she spotted a giraffe striding along. "Please, dear giraffe," shouted the hornbill, "would you be so kind to carry us back to my nest?" "No, way," said the giraffe, "I would look silly, no indeed," and he stalked haughtily away nibbling at the treetops. Suddenly he noticed that his feet were caught in the tangle dangle vine. He began kicking wildly, but the more he kicked, the more he entangled he became, until he couldn't move anymore.

So the ant, the turtle, the bird, and the giraffe were left in deep trouble until a huge, good-natured elephant came along. He helped the ant by reaching his long trunk out over the river and lifting him back to dry land. He gently flipped the turtle back onto his feet with the tip of his trunk. He cautiously carried the egg up to the nest and finally he undid the tangle around the giraffe's legs. However, only the little ant whispered a thank-you; all the others just turned around and went their way.

The elephant was enormously pleased with himself continuing to strut about in the jungle. He didn't notice that there was a deep ravine just ahead and before he knew it he tumbled straight into it. "Help, help," he bellowed, but nobody came. Finally, when he had almost given up, he heard the sound of tiny footsteps from somewhere above. "Who's there", he called out. To his great surprise he caught 
the voice of the friendly ant he rescued earlier this morning. "I came with nintyfive thousand friends to help you," he said. The elephant laughed: "But you cannot possibly lift me out of here!" "Oh yes, we can! Come on friends, let's get to work!" A teeming horde of ants swarmed under the elephant and slowly, very slowly moved the huge animal upwards. When he finally had reached the top, the elephant was very happy and humbly offered the ants a ride back home to their ant hill. 


\section{APPENDIX B}

CECILIA

\begin{tabular}{|l|l|l|}
\hline Events/ Features & Character & Places \\
25 & 5 & 5 \\
\hline 1.. Cecila lebte im Ocean & Seeungeheu & Ocean \\
2. man brauchte keine Angst zu haben & e & (Wasser) \\
3. schwamm umher und langweilte sich & Kapitän & Windrose \\
4. es bemerkte Segelschiff & Passagiere & Piratenschif \\
5. folgte ihm & alte Dame & f \\
6. das Schiff kam in Windstille & Piraten & Küste \\
7. Passagiere ängstlich und aufgeregt & & (Land) \\
8. Cecilia holte tief Luft und begann zu pusten & & Insel (Land) \\
9. Windrose segelte aus Windstille heraus & & \\
10. Kapitän warnt vor einem Sturm & & \\
11. alte Dame schreit aus Leibeskräften & & \\
12. Cecila rollt Schwanz um das Schiff, holt Luft & & \\
13. Windrose schwebt wie auf Rettungsring & & \\
14. Cecila taucht unter, um sich auszuruhen & & \\
15. Piratenschiff verfolgt Windrose & \\
16. Windrose flieht, um zu entkommen, & \\
17. Piraten sind schneller & \\
18. Piraten schiessen Segel von Windrose kaputt & & \\
19. Cecila taucht unter und zerschmettert & \\
Piratenschiff & \\
20. Cecila hat Kopfschmerzen & \\
21. Passagiere haben Angst vor Cecila & \\
22. Cecila zieht Windrose hinter sich her & \\
23. Cecila zieht Windrose an die Küste & \\
24. alte Dame bedankt sich & \\
25. Cecila schwimmt zur Insel und schläft 1 Monat & & \\
\hline
\end{tabular}


RUFUS

\begin{tabular}{|l|l|l|}
\hline Events/ Features & Character & Places \\
25 & 6 & 3 \\
\hline 1...In Afrika wohnte ein Löwe & Löwe & Afrika \\
2. war schwach, konnte nicht brüllen & Geier & Baum \\
3. musste Essen mit Geiern teilen & (Freunde) & Sumpf \\
4. mochte diese Vögel nicht & Schakal & \\
5. Schakal hat Geier gepackt & (Tier) & \\
6. Rufus drehte sich um & James & \\
7. Rufus verjagte Schakal & (Vogel) & \\
8. James bedankte sich & Jäger & \\
9. Rufus will seine Ruhe haben & Krokodil & \\
10. Geier bewundern Rufus und folgen ihm & & \\
11. Rufus ärgert die Störung & & \\
12. Geier wollen Rufus helfen & & \\
13. James entdeckt Jäger auf Löwenjagd & \\
14. "Rufus, Jäger kommen"! & \\
15. Rufus läuft hinter James zum Sumpf & \\
16. Oh Schreck, ein Krokodil & \\
17. Rufus hat Angst & \\
18. James schrie:"Stell dich tot"! & \\
19. Rufus rollte sich auf den Rücken, machte Augen \\
zu & & \\
20. James holte seine Freunde & \\
21. Geier pickten Rufus mit den Schnäbeln & \\
22. Jäger waren erstaunt, dass Löwe tot war & \\
23. Jäger waren verschwunden & \\
24. James freut sich wie gut Rufus schauspielerte \\
25. Rufus freut sich, dass er nicht mehr alleine ist & & \\
\end{tabular}


MAGNUS

\begin{tabular}{|c|c|c|}
\hline $\begin{array}{l}\text { Events/Features } \\
25 \\
\end{array}$ & Character 6 & \begin{tabular}{|l} 
Places \\
7
\end{tabular} \\
\hline $\begin{array}{l}\text { 1. A. krabbelt Blattstengel empor um Fluss zu } \\
\text { besehen } \\
\text { 2. Windstoss blies sie aufs Wasser } \\
\text { 3. Baumstumpf festkrallen } \\
\text { 4. Bitte, Schildkröte,würdest Du mich } \\
\text { zurückbringen? } \\
\text { 5. Schildkröte schüttelt den Kopf } \\
\text { 6. Schildkröte sucht einen Stein } \\
\text { 7. Schildkröte landet auf dem Rücken } \\
\text { 8. Bitte, Nashornvogel, kannst du mir helfen? } \\
\text { 9. Nein, auf keinen Fall! } \\
\text { 10.Vogelei fällt aus dem Nest } \\
\text { 11.Nashornvogel konnte es nicht aufpicken } \\
\text { 12.Bitte, Giraffe, ...Ei wieder ins Nest heben? } \\
\text { 13.Nein, ich säh dumm aus! } \\
\text { 14.Giraffe verheddert sich im Gestrüpp } \\
\text { 15.Bleibt erschöpft liegen } \\
\text { 16.Alle Tiere sind in Not, als Magnus vorbeikommt } \\
\text { 17.Hebt Ameise ans Ufer } \\
\text { 18.Rollt Schildköte auf den Rücken } \\
\text { 19.Hebt Ei ins Nest } \\
\text { 20.Befreit Giraffe vom Gestrüpp } \\
\text { 21.Läuft stolz trompetend weiter } \\
\text { 22.Stürzt in die Grube } \\
\text { 23.Ameise kommt mit ihren Freunden zu Hilfe } \\
\text { 24.Bewegen ihn aus der Grube und kitzeln ihn } \\
\text { 25.Nicht mehr stolz bringt er die A. nach Hause } \\
\text { 1. }\end{array}$ & $\begin{array}{l}\text { Ameise } \\
\text { Schildkröte } \\
\text { Nashornvo } \\
\text { ge } \\
\text { (Vogel) } \\
\text { Giraffe } \\
\text { Elephant } \\
\text { Freunde } \\
\text { (Ameisen) }\end{array}$ & $\begin{array}{l}\text { Fluss } \\
\text { (Wasser, } \\
\text { Grashalm) } \\
\text { Blattstengel } \\
\text { (Baum) } \\
\text { Baumstum } \\
\text { pf } \\
\text { (Ast) } \\
\text { Ufer (Land) } \\
\text { Stein } \\
\text { Nest } \\
\text { Grube } \\
\text { (Berg, Loch, } \\
\text { Graben, } \\
\text { Weg) }\end{array}$ \\
\hline
\end{tabular}




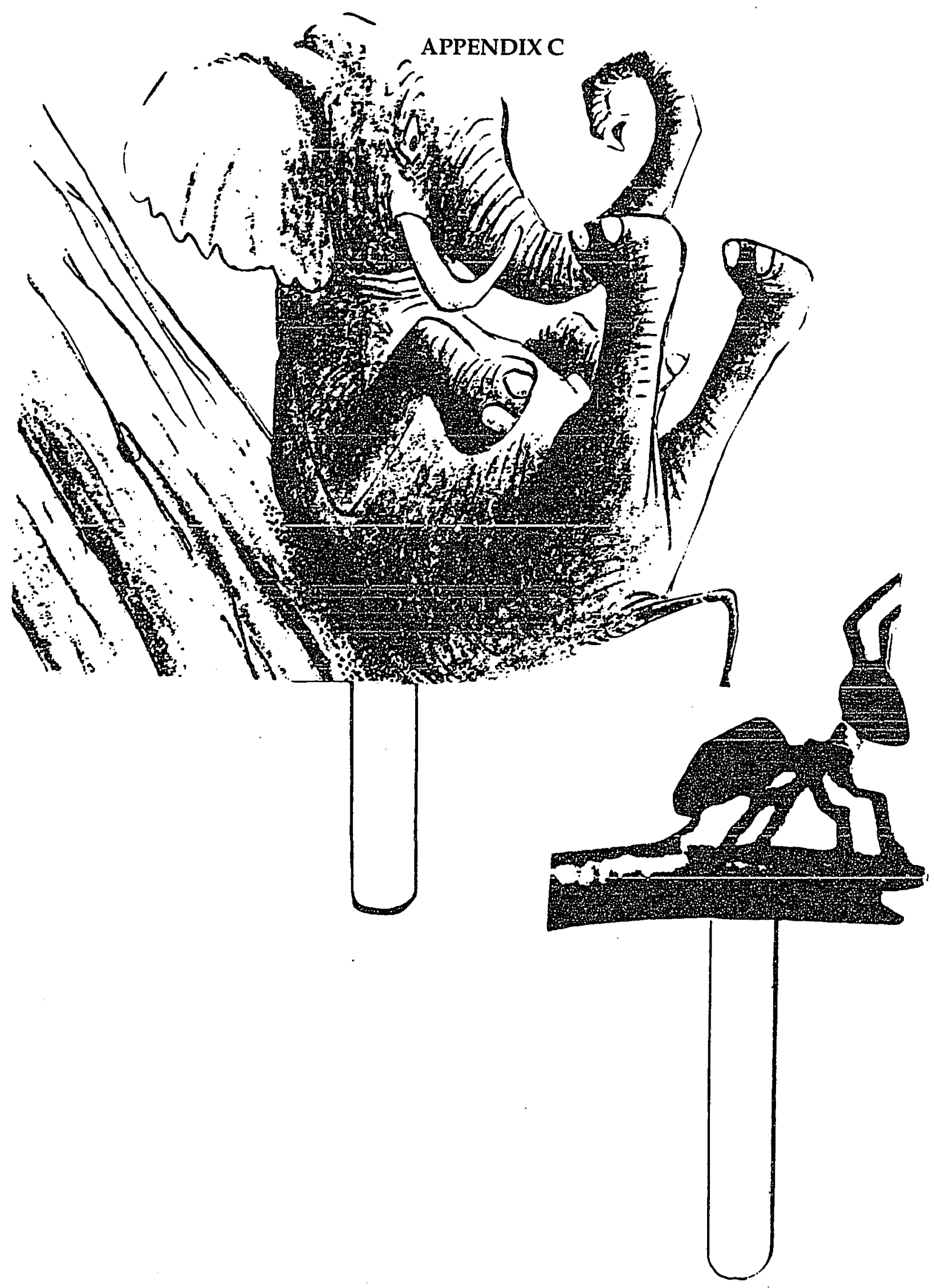




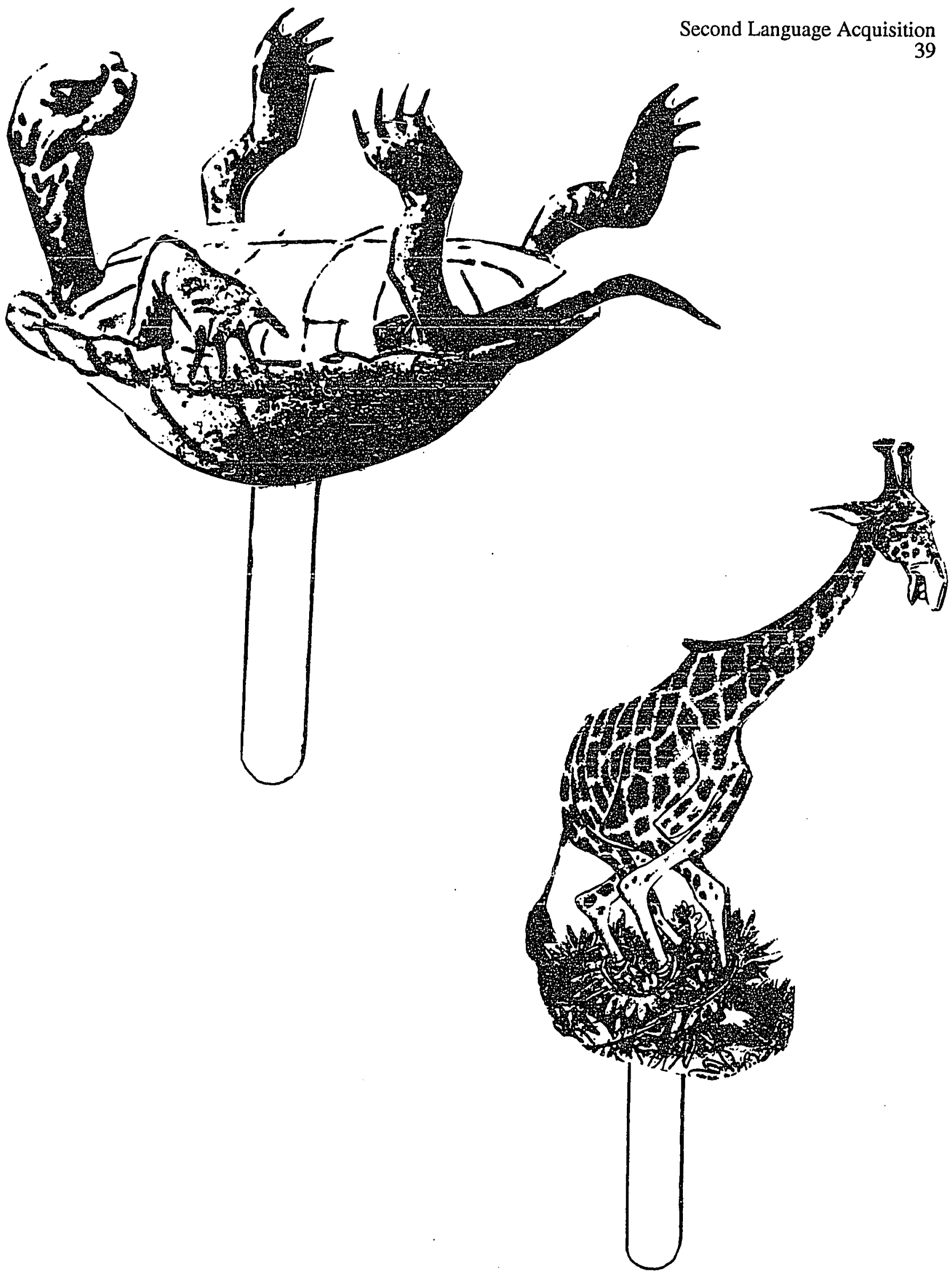




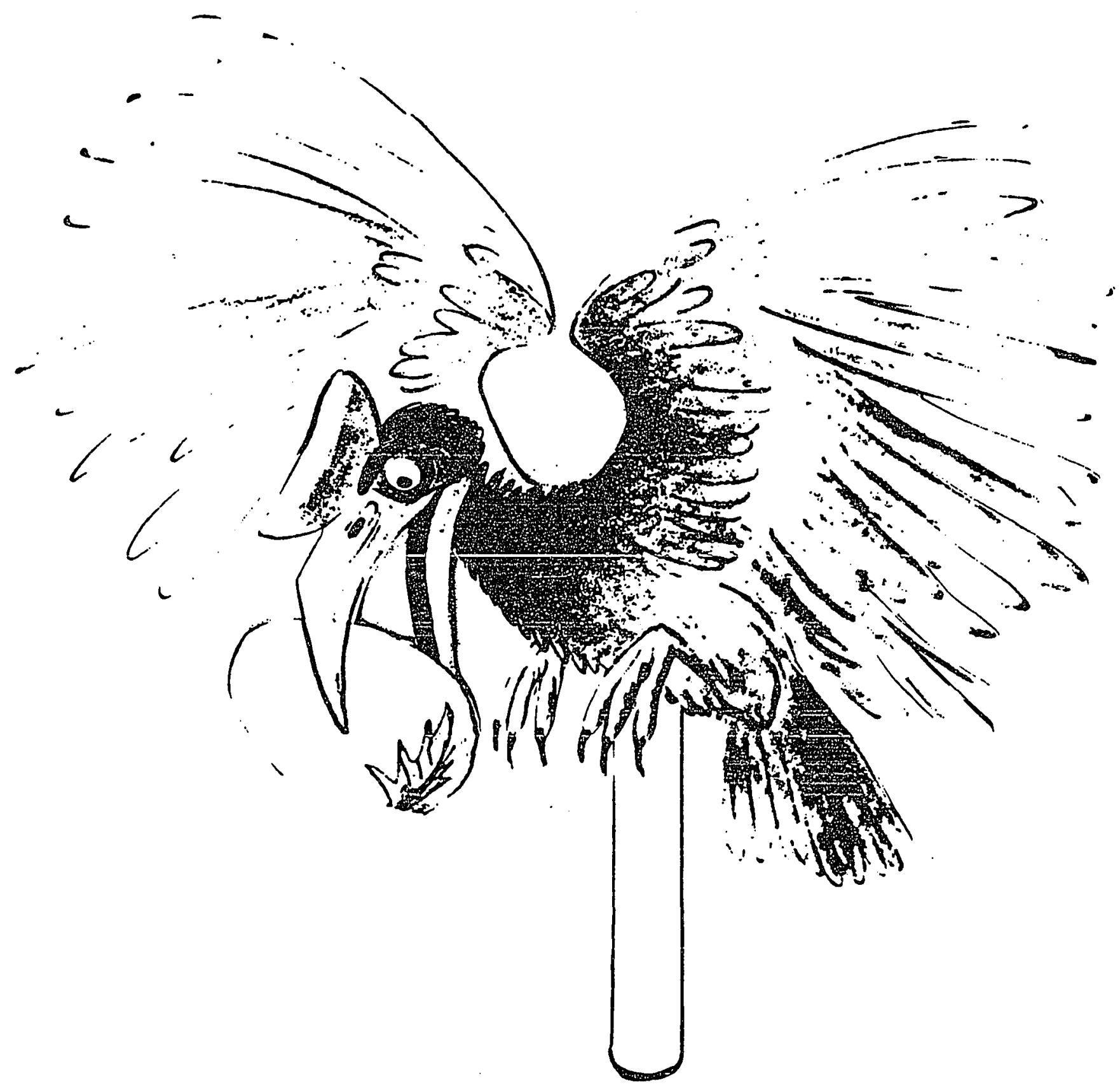


Children's Stories

\section{APPENDIX D}

\section{Cecila (Story 1)}

\section{Child 1}

Ein Mädchen.(who was she?)...ins ins ins...ich weiss es nicht. (What else happened in the story). Die Naselia hat den Schiff gefunden.

Sie war, da war drei Männer. Auf dem Land. (What happened?) Vielleicht ist es zu heiss für ihn und dann sind sie in Boot gegangen. Dann war, dann war Naselia und dann hat die Naselia es gefunden und dann hat er, dann hat der Wind geblasen für drei Tagen und dann ist es aufgehört. Und dann... hat sie tiefes Luft geschluckt und dann hat sie pfffff bis der Boot gegangen ist. Dann hat der Pirat gekommen, die wollen sie fangen... (What happened then?) Dann ist Naselia ins Wasser gesprungen...sie hat die Boot ge...ge...ge...weiss es nicht. (What happened then). Sie hat geschlafen, weil sie müde ist. (Why?) Weil sie hat gearbeitet. (What happened at the end). Sie hat ihn gezogt zu den Iand. (Do you remember anything else?) Eine Frau, die hat Danke-Schön zu Naselia gesagt.

\section{Child 2}

...(silence) ...(What happened in the story you heard this morning)...(Who was Cecilia?) ... I don't know. (Do you remember anybody else in the story?) Leute...(What happened to them)...geholft... (Who helped them?)... Ich weiss nicht... (I don't know).

\section{Child 3}

Eine Haus. (What happened). Ist kaputtgegangen. Laufen in Luft. I can't get it out. Dann hat Haus runterziehen. (What happened then?) She hat es gebrochen, kaputtgemacht. Und das Schiff machen neue Schiff, neumachen. (Do you remember anything else?) Nein (No).

\section{Child 4}

Am, das Schiff mit dem Kaptän und der Frau und den Matrosen das war dann in Windstille und dann hat das Seeungeheuer ganz doll gepustet, so dass das Schiff wieder weiter geschwommen ist... (What happened then?) Dann kam ein Piratenschiff, und wollte das überfallen dann ham die alles getan was sie nur 
konnten damit sie fliehen konnten aber die Piraten warn schneller und die ham ihr Segel kaputtgeschossen und dann hat die Cecila das andere Schiff kaputtgemacht und das Schiff, das Schiff mit den anderen Leuten das hat sie nach Westen zum Land gezogen. (And then) Die war ganz müde und da ist sie auf ne Insel geschwommen und hat da einen Monat lang geschlafen.

\section{Child 5}

Da war ein Piratenschiff und da hat der Kapitän gesagt die sollen schnell hinter das Segel gehen und dann, dann dann ham ses gemacht, aber die die die paar von den Piraten die Kanonen ham durch die Segel geschossen. (What happened then?). Dann, dann vorher kam ein Sturm und die hat, die hat ganz tief Luft geholt und dann, dann, dann nämlich... dann hat die ihren Schwanz darum gewickelt. (Who?). Die hinter dem Boot hergeschwommen ist. Es war ein Ungeheuer. (What else happened? ) Es hat das grosse Schiff zu einem Land gebracht dass war dann das Ende. Dann ist se zu einem ruhigen Land geschwommen und eingeschlafen.

\section{Child 6}

Die, die, die wollte...der Kapitän,...ich weiss nicht (I don't know). (Start from the beginning) ...er hat gesagt, dass das Schiff untergeht...(and then?)...die hat das hochgeschoben...(and then?)...dann ist es wieder hoch, und dann hat er, und dann sind die bald zum Land gekommen...ich will nicht mehr erzählen (I don't want to tell anymore). 


\section{Rufus (Story 2)}

\section{Introduction in English given by the teacher}

This story talks about an old lion named Rufus. He is too weak to hunt for food thus he has to share the left -overs with the vultures. One day he helps one vulture which is attacked by an animal. The vultures are so grateful that they follow Rufus everywhere. One day he is followed by a group of hunters and this time the flock of vultures rescued Rufus. They became good friends after all. And now I'm going to tell you the story in German.

\section{Child 1}

Er kann nicht sein eigenes Essen holen. (Why). Weil er alt ist. (What happened then?) Ein Vogel hat eine Falle gemacht. Dann hat der Löwe ihn rausge...rausgezieht. Dann kommen Jäger. (What happened then?) Totmachen, die Vögel wollten nicht, dass die Rufus tot wird. Rufus muss zu ein Versteck tun, da war ein Krokodil. Da hat er gesagt...ich weiss es nicht...(what did the birds do?) Der sollte tot werden, aber der ist nicht tot, dann hat die Geier gemacht, nur, nur nicht wirklich ihn essen aber probieren zu essen. Dann glauben sie dass sie schon tot war. Dann ham sie da ihn gelegen....(Anything else?) No...

\section{Child 2}

Ein Löwe, der hatte Vögel... die Freunde... James. (What did he do). Helft ihn, die sehn Jäger. (Do you remember anything else?) Nein, weiss nicht...

\section{Child 3}

The lion got hurt, he got to the ship. (Can you tell me in German). This is in Deutsch. Der Lion hat eine kranke Medizin gehabt und der hurt himself. Und der hat Freunde gehabt und der hat gehauen. (What happened then?) Und die wollten ihn fangen. Er kann die doch beissen. (Do you remember anything else). Der er muss machen zum heimgehen, der will schlafen...(Anything else)...No.

\section{Child 4}

Der Löwe der war ganz schwach und hatte immer nichts zu essen deswegen musste er sein Essen mit den Geiern teilen. Der mochte die Geier nicht so gerne weil die so laut und weil die immer tote Sachen assen. Und dann hat einmal ein 
Tier den James den Geier am Flügel gepackt und da hat der Löwe das Tier verjagt und da ham die Geier immer den Löwen gefolgt. Das wollte er immer nicht und dann irgendwann hat dann James Jäger gesehen und die wollten, die hatten grosse Speere und die warn auf Löwenjagd, und dann ist der Löwe schnell zum Fluss gegangen und dann kam ein Krodokil und dann hat er sich totgestellt und dann kam die Jäger aber die Geier ham so getan als ob sie ihn aufessen und dann ham die Jäger gedacht der war tot und die wollten keine toten Tiere nehmen. Und dann weiss ich nicht mehr weiter (This is all I know).

\section{Child 5}

Da kam drei Jäger und die wollten auf Löwenjagd gehen und da hat der eine Vogel gesagt er soll sich ganz still hinlegen und dann dann als die Jäger da waren, dann ham die gesagt dass der Löwe schon gestorben ist, aber der war noch gar nicht gestorben. (..(Do you remember anything else?) Nein...

\section{Child 6}

Der Rufus ist noch so alt, der hat immer totes Fleisch gegessen. Der war ein Löwe, der hat im Wald in Afrika gewohnt... (What happened there). Da sind Jäger gekommen, die wollten ihn töten und seine Freunde ham gesagt er soll weggehen, der soll sich hinlegen. (Do you remember anything else?) Nein... 


\section{Magnus (Story 3)}

\section{Introduction in English given by the teacher}

This story talks about four animals which are all in deep trouble. The ants asks a turtle to help her out, but she refuses. The turtle then asks a bird to help her out, but he refuses. The bird asks a giraffe to help her out, but she refuses as well. Finally, the giraffe gets into trouble, too. Fortunately, a good-natured elephant comes along and helps out all four animals. Then he gets into trouble himself, but is helped by the ant.

\section{Child 1}

Ein Elephant... , ein Vogel und ein Giraffe und Ameise... (What happened to them, do you remember?) Ja, die Schildkröte ist umgefallen...der Vogel hat ein Ei, ein Ei, ein Ei runtergefallen, ahm, hat er versucht, den aufzuheben... (And then?) Die Ei war starker, die Vogel war stark, aber die Ei war starker. (What happened to the other animals?) Der wollte auf ein Baum gehen dann blass der Wind und dann ist er aufgefallen auf die Baum... (What happened then?) Er fragt die Schildkröte...(Who else was in the story?) Giraffe,...die Pflanzen hat sie auf den Beinen gehalten ...(And then?) er hat sie rausgezogen, er hat sie geholfen. (What happened to the elephant?) Der hat seinen Weg verloren, da bleibt er, endlich und dann, dann kommt die Ameise, die haben ihn rausgezieht. (What happened then?) Ihn auf den Rücken zu heim brachten, die Ameisen. (Anything else?) Nein...

\section{Child 2}

Magnus, ein Elephant,...(who else was in the story?) eine Giraffe, eine Schildkröte, Ameise, Vogel... (Do you remember what happened) Ja, die Ameise hat in die Wasser gefallen und hat den Schildkröte gesagt kannst Du mir helfen und die Schildkröte hat gesagt nein. Die Schildkröte musste auch landen, so...(falls on the floor on her back) sie hat die Vögel kannst du mir helfen und die Vögel sagt nein. Die Vögel hat ihre Ei runtergemacht und sie sagt die Giraffe, kannst du mir helfen. Die Giraffe hat gesagt nein. Die Giraffe... (what happened to her?) ich weiss nicht...(What happened then?) Die Elephant, die Ameise auf Land gemacht, die ...ahm...Schildkröte umdrehen, die Vögel's Ei in die Nest rein, und die Giraffe...ich weiss nicht (I don't know).(What happened to the elephant?) 
Sie hat ihn, ihn hat uuuuhhhh (falls over on the floor)... (What happened then?) Alle Ameisen hat gehelfen, rausgeholt aus Loch... (And then?) Auf ihren Rücken getragen, auf die Elephants Rücken getragen...ich weiss nicht mehr (I don't know anymore).

\section{Child 3}

De Elephantgeschichte...de fallen runter von die Berg. und die ham ihn raufgeschoben, pushed him up, de Berg... (Who else was there?) Andere Tiere? Eine Schildkröte, aufgehebet und der hat geschlafen, eine lion kam und der hat gehauen.. (who else?) eine Giraffe, eine, ein Vogel... (What happened?) Giraffe, der hat he hurt himself bei de Berg. Der ihn aufgeschoben... (Who) eine Vogel. He did hurt himself... (Do you remember anything else? Nein...(No). 


\section{Child 4}

Da war eine Ameise und die ist auf einen Grashalm geklettert weil sie einen Fluss besser betrachten wollte und dann wollte sie raufklettern und dann ist sie auf einem Baumstumpf geweht worden, ist sie ins Wasser geweht worden aber konnte sich noch am Baumstumpf festhalten. Dann hat sie eine Schildkröte gefragt ob sie helfen kann und die hat gesagt nein. Und dann wollte die Schildkröte auf nen Stein klettern da ist sie auf den Rücken gefallen und konnte nicht mehr auf die Beine und dann ist dieser Vogel gekommen und dann hat die Schildkröte den Vogel gefragt, der wollte nicht. Und dann ist sein $\mathrm{Ei}$ runtergefallen und er konnte sein Ei nicht mehr hochtun und dann ist eine Giraffe und die und dann hat der Vogel gefragt ob die Giraffe ihn helfen kann aber die Giraffe wollte nicht und dann die Giraffe die Beine verheddert im Gestrüpp und dann warn die alle in Not. Und dann ist ein Elephant gekommen und dann hat er die Ameise aufs Land getan, die Schildkröte wieder umgedreht, den Vogel sein Ei ins Nest gelegt und die Giraffe befreit. Und dann war er so stolz und is in eine Grube gefallen und da konnte er nicht $m$ ehr raus. Dann hörte er ganz viele kleine Schritte und dann kam die Ameisen und die ham ihm rausgeholfen. Und dann war er gar nicht mehr so stolz wie vorher und dann hat er die Ameisen nach Hause getragen.

\section{Child 5}

Von Elephanten. Die eine Ameise sagt...da kam etwas angelaufen und das macht pfffff (blows) und dann ist die Ameise vom Baum runter gefallen aber sie hat sich noch an eim Ast festgeklammert. dann hat se gefragt die Schildköte ob sie die Raupe da wieder hinbringt aber dann hat se gesagt, ach nein, sei das nächste Mal nicht so tolpatschig...(And then?) Dann kam so ein Vogel, ein Nashornvogel und der, der hat da is ihm dann das Ei aus dem, das schwere Ei aus dem Nest gefallen und dann kam die Schildkröte, ich weiss nicht, etwas, ich weiss es nicht mehr was das hat dann versucht es wieder hochzubringen aber das Ei war zu schwer und dann, dann, dann kam der Elephant und der hat die Schildkröte, die ist hingefallen auf den Rücken und dann kam der Elephant und hat se wieder umgedreht das Ei in das Nest und dann ahm. dann nämlich der hat rumgetrötet und der hat gar nicht gemerkt das der Boden von ihm weg war auf einmal und da ist er in den Graben gefallen und dann hörte er was tippeln und da hat die 
Ameise ganz viele Freunde geholt und die, und die hatten dann den Elephanten wieder rausgeholt.

\section{Child 6}

Ein kleiner Elephant..., ich kann mich gar nicht mehr erinnern ( who else was in the story?) ein Nashornvogel, ein Giraffe...eine Ameise...eine Schildkröte. (What happened?) Da sind ganz,auf einmal ganz, eine, viele Ameisen auf den Magnus, auf den Elephanten, ahm, auf den Rücken ganz viele Ameisen gekommen. (What happened before that?) Die Ameise war auf den Baum und da hat die Schildkröte.gesagt, -heh was ist denn da-,... (What happened then?) die Schildkröte sollte tragen und da hat die Schildköte, nein, nein, nein gesagt. Und der Nashornvogel der hat mit seinem Schnabel ein Ei gepickt, aber das konnte er nicht mit dem Schnabel.......(Who came then?). Der Magnus der Elephant, der hat dann gekommen und alle Tiere getragen. (Why?) ...weil die eine Ameise gekommen ist die ham den Magnus gekitzelt und ihn nach Hause getragen.

(What happened then). Weiss ich nicht...(I don't know?) 


\section{APPENDIX E}

\section{Raw Data}

\section{Cecilia}

\begin{tabular}{|c|c|c|c|c|c|c|c|c|c|c|c|c|c|}
\hline & & 6 & & 5 & & 4 & & 6 & & 5 & & 4 & \\
\hline & 100 & $\begin{array}{l}\text { yrs } \\
\text { Ch }\end{array}$ & $\%$ & $\begin{array}{l}\text { yrs } \\
\text { Ch }\end{array}$ & $\%$ & $\begin{array}{l}\text { yrs } \\
\text { Ch }\end{array}$ & $\%$ & $\begin{array}{l}\text { yrs } \\
\text { Ch }\end{array}$ & $\%$ & $\begin{array}{l}\text { yrs } \\
\mathrm{Ch}\end{array}$ & $\%$ & $\begin{array}{l}\text { yrs } \\
\text { Ch }\end{array}$ & $\%$ \\
\hline & $\%$ & 1 & & 2 & & 3 & & 4 & & 5 & & 6 & \\
\hline Events & 25 & 8 & 32 & 1 & 4 & 2 & 8 & 10 & 40 & 6 & 24 & 3 & 12 \\
\hline Charac & 5 & 2 & 40 & 1 & 20 & 0 & 0 & 4 & 80 & 3 & 60 & 1 & 20 \\
\hline Places & 5 & 3 & 60 & 0 & 0 & 1 & 20 & 4 & 80 & 3 & 60 & 2 & 40 \\
\hline Total & 35 & 13 & 37 & 2 & 6 & 3 & 9 & 18 & 51 & 12 & 34 & 6 & 17 \\
\hline
\end{tabular}

\begin{tabular}{|c|c|c|c|c|c|c|c|c|c|c|c|c|c|}
\hline & $\begin{array}{l}100 \\
\%\end{array}$ & $\begin{array}{l}\text { Chi } \\
\mathbf{1}\end{array}$ & $\%$ & $\begin{array}{l}\text { Chi } \\
2\end{array}$ & $\%$ & $\begin{array}{l}\text { Chi } \\
3\end{array}$ & $\%$ & $\begin{array}{l}\text { Chi } \\
4\end{array}$ & $\%$ & $\begin{array}{l}\text { Chi } \\
5\end{array}$ & $\%$ & $\begin{array}{l}\text { Chi } \\
6\end{array}$ & $\%$ \\
\hline Events & 25 & 11 & 44 & 2 & 8 & 2 & 8 & 13 & 52 & 3 & 12 & 4 & 16 \\
\hline Charac & 6 & 4 & 67 & 4 & 67 & 1 & 17 & 6 & 100 & 3 & 50 & 3 & 50 \\
\hline Places & 3 & 1 & 33 & 0 & 0 & 0 & 0 & 1 & 33 & 0 & 0 & 1 & 33 \\
\hline Total & 34 & 16 & 47 & 6 & 18 & 3 & 9 & 20 & 59 & 6 & 18 & 8 & 24 \\
\hline
\end{tabular}

100 Chi \% $\quad$ Chi $\%$ Chi $\%$ Chi \% Chi \% Chi \% $\begin{array}{llllllll}\% & 1 & 2 & 3 & 4 & 5 & 6\end{array}$

$\begin{array}{llllllllllllll}\text { Events } & 25 & 12 & 48 & 14 & 56 & 4 & 16 & 23 & 92 & 13 & 52 & 9 & 36\end{array}$ $\begin{array}{llllllllllllll}\text { Charac } & 6 & 6 & 100 & 5 & 83 & 4 & 67 & 6 & 100 & 5 & 83 & 5 & 83\end{array}$ $\begin{array}{llllllllllllll}\text { Places } & 7 & 1 & 14 & 4 & 57 & 1 & 14 & 7 & 100 & 4 & 57 & 1 & 14\end{array}$ $\begin{array}{llllllllllllll}\text { Total } & 38 & 19 & 50 & 23 & 61 & 9 & 24 & 36 & 95 & 22 & 58 & 15 & 39\end{array}$ 